Delphine Thivet. Peasants' Transnational Mobilization for Food Sovereignty in La Vía Campesina. In Carole Counihan and Valeria Siniscalchi (eds), Food Activism : Agency, Democracy and Economy, Bloomsbury, pp.193-209, 2013.

\title{
Peasants' Transnational Mobilization for Food Sovereignty in la Vía CAMPESINA
}

\author{
Delphine Thivet
}

\begin{abstract}
:
This paper examines how small farmers and landless rural workers have developed new modes of food activism at the transnational level. It explores in particular how the international peasant movement $L a$ Via Campesina advocates and seeks to build - through the concept of the "food sovereignty" - an alternative frame for food production and distribution enabling communities and people to determine at the local/national level their own food systems. Based on a multi-sited fieldwork including participant observations and interviews with organizations' members from three different countries involved in La Via Campesina (France, Brazil and India), my study analyses the various and unstable definitions of the concept of "food sovereignty" in the movement. It examines the process of adding new meanings to its definition according to its circulation across different scales and specific cultural and geographical contexts, its attempted legal translations, and its local reconfigurations in sometimes nationalistic and protectionist ways. The aim is first to show how the demand for "food sovereignty" has emerged at the international level so as to reframe politically global food relations and compete with a more technical response to world hunger promoted by global institutions - the notion of "food security". The paper then traces the various strategies used by La Via Campesina's activists to legitimize and promote their cause, trying to make small-scale farmers "visible" - both in international and national public arenas - and recognized as those assuming a leading role in food production throughout the world. Finally, it addresses the way the food sovereignty framework catalyzes social mobilization across borders by constituting transnational interests and provides to marginalized social agents in the countryside a conceptual frame for making sense of the process of dispossession from the means of production they have been undergoing since the early 1980s.
\end{abstract}

The concept of "food sovereignty" was introduced for the first time in a public arena in 1996:

Food is a basic human right. This right can only be realized in a system where food sovereignty is guaranteed. Food sovereignty is the right of each nation to maintain and develop its own capacity to produce its basic foods respecting cultural and productive diversity. We have the right to produce our own food in our own territory. Food sovereignty is a precondition to genuine food security. (La Vía Campesina 1996)

From that time forward, the concept of food sovereignty has been identified as the key motto of La Vía Campesina ${ }^{1}$. This transnational social movement was born in May 1993 in Mons (Belgium) to oppose the negative social impacts of neoliberal economic globalization of agriculture. Since then, it has continued to grow, attracting more and more organizations from all over the world. Organized into nine regional secretariats, a rotating International Operative

\footnotetext{
* Ecole des Hautes Etudes en Sciences Sociales, EHESS, Paris, France

${ }^{1}$ La Via Campesina refers in English to the "Peasant Way" or the "Peasant Road".
} 
Secretariat $^{2}$, an International Coordination Committee (ICC), and various commissions or working committees, La Vía Campesina has a rather heterogeneous membership (Borras 2008: 274). It is now comprised of 150 rural organizations made up of peasants, small and mediumholder farmers, organic farmers, rural women, rural workers, indigenous and landless from the Americas, Asia, Europe and Africa, and representing about 200 million members from seventy countries. The term "food sovereignty" was originally coined by farmer and landless activists during the Second International Conference of La Via Campesina, which was held in Tlaxcala, Mexico in 1996. The term offered an alternate concept to "food security," which was advocated and promoted by the United Nations Food and Agriculture Organization (FAO) and the World Bank. Since 1996, food sovereignty - broadly defined as the right of each nation or people to define their own agricultural and food policies - has been adopted by various nongovernmental organizations (NGOs), development advocates, environmental groups, academics, and even by certain nation states and governments such as Venezuela, Bolivia, Ecuador, Mali ${ }^{3}$, and Nepal as a strategic goal to promote change in the current food system.

The present paper explores how, under the banner of food sovereignty, small farmers and landless rural workers have contributed to reframing the debate on world hunger and asserted the democratization of the food system by developing a new mode of agri-food activism at the transnational level. Drawing theoretically on frame analysis developed by David Snow, Robert Benford, and their collaborators (1986) and on the available literature on social movements, I will show how the concept of food sovereignty provides men and women engaged in smallscale agriculture with possibilities to resist the process of intensified marginalization and impoverishment that they have been undergoing since the 1980s and 1990s as a result of structural adjustment programs and bilateral/regional free trade agreements. The paper also will show how the concept serves as a catalyst to bring them together and sustain their collective action across borders.

Since its creation, the concept of food sovereignty has been undergoing continual reformulations, which sometimes result in conflicting interpretations in the course of its circulation across different geographic and socio-cultural contexts ${ }^{4}$. In spite of its potentially unstable meaning, it has nonetheless fostered among smallholder farmers in both the South and the North a shared understanding of the impacts of the implementation of neoliberal policies in agriculture and urgency to act in concert with other social agents to bring about a change in the global food system. The participants in La Vía Campesina have indeed undergone a common deepening sense of dispossession from their means of production since the Uruguay Round of the General Agreement on Tariffs and Trade (GATT) in the early 1990s. It was precisely to

\footnotetext{
${ }^{2}$ The International Operative Secretariat was established in 1996, even though it was informally located in Europe (Bruxelles) and held by Paul Nicholson, member of the Basque Farmers' Union (Euskal Herriko Nezakarien Elkartasuna- EHNE) previously from 1993 to 1996. Then it moved to Central America, in Honduras, and was held by Rafael Alegría, member of the Honduran Coordinating Council of Peasant Organizations (Consejo Coordinador de Organizaciones Campesinas de Honduras-COCOCH). Since 2004, it has been based in Jakarta (Indonesia) and held by Henry Saragih, Secretary General of the Federation of Indonesian Peasant Unions (Federasi Serikat Petani Indonesia-FSPI). In June 2013, the International Operative Secretariat has moved to Africa, in Zimbabwe and is now hosted by the Zimbabwe Small Organic Farmers Forum (ZIMSOFF). For more insights into La Via Campesina organizational structure and decision-making process by consultation and consensus, see Desmarais 2007a: 28-30 and Martínez-Torres and Rosset 2010: 164-166.

${ }^{3}$ Even if "food sovereignty" has been included in its Agricultural Orientation Law in 2006 (Title I, Article 3; III, Article 51), many ambiguities surround current agricultural policies in Mali, in particular large-scale land acquisitions by foreign investors such as Malibya in June 2008 (Libyan lease of 100,000 ha of farmland). Marie Hrabanski also shows how "food sovereignty", in the case of Senegal, has been exploited by President Abdoulaye Wade for petty political ends (2011).

${ }^{4}$ On the importance of socio-cultural circumstances in which the framing process takes place and the dynamic instabilities in the very process of discourse ("multivocality"), see for instance Steinberg 1999.
} 
challenge the increasing global concentration and integration in the food chain and in agriculture that they decided to converge transnationally towards what can be qualified a radical agrifood activism. As I shall show, this activism combines discursive practices and direct action protests, along with alternative agro-ecological initiatives and emancipatory politics.

The chapter begins by describing how La Vía Campesina activists originally framed the concept of food sovereignty. I shall show that, through the reshaping of existing human rights language and food security discourse, they gave rise to an interpretative frame which challenged and drew new meanings in the hegemonic discourse of institutions on world hunger and put forward a more comprehensive understanding of the production and distribution of food. In the second section, my analysis focuses on how they challenged the invisible nature of small peasants in the international arena by asserting their status as "food producers", but also by undertaking direct protest actions against the corporate control of the global food system. The third and last section moves to La Via Campesina's commitment to social change. Herein I examine in particular how the movement promotes self-reliant farming based on "seed sovereignty" and agro-ecological practices and how it challenges inequalities of power in the food system through a feminist orientation.

The ethnographic fieldwork that informs my paper was carried out between 2009 and 2012 as a part of my Ph.D. project on the transnationalization of solidarities and farmers' movements. It consists of about sixty semi-structured interviews conducted with international delegates of La Vía Campesina from the ICC, international and regional technical support staff, national farmer and landless leaders, and local activists of organizations taking part in La Vía Campesina, most in France, Brazil and India. ${ }^{5}$ My study also includes participant observation of rallies and public meetings at the national and international levels and extensive archival research on the sociogenesis of La Vía Campesina since the early 1990s.

\section{Re-framing the World Hunger Problem}

Following Benford and Hunt's (2003) constructionist analysis on public problems, one approach to understand the food sovereignty mobilization by La Via Campesina may be linking it to the social construction of the world hunger problem. Indeed, while the latter is now recognized as a major issue on the global public agenda ${ }^{6}$, definition and interpretation of its specific causes and potential remedies still constitute by themselves a "contested terrain" (Benford and Hunt 2003: 154). To understand the key role the concept of food sovereignty plays in the politicization of food politics and world hunger problem, I refer to "framing" as the signifying work or construction of meanings by social movement activists; that is to say, "the struggle over the production of mobilizing and counter mobilizing ideas and meanings" (Benford and Snow 2000: 614).

As a concept naming the problem of world hunger and malnutrition, "food security" has occupied a prominent place on the international agenda since the 1970s. If it is difficult to trace a consensual definition of "food security", as its conceptualization has shifted over time. One

\footnotetext{
${ }^{5}$ To deepen the understanding of the transnationalization of farmers' movements, my Ph.D. project takes a comparative and multi-sited approach in focusing on three organizations of La Via Campesina (the Confédération paysanne from France, the Movimento dos Trabalhadores Rurais sem Terra - MST - from Brazil and the Karnataka Rajya Ryota Sangha - KRRS - from India) and examines how they are building solidarities beyond and across national borders.

${ }^{6}$ According to statistics by the FAO, over one billion people — that is, one in six human beings — are hungry in the world.
} 
of the first and significant occurrences of the term was found during the FAO World Food Conference in 1974, following the world oil crisis and related food crisis of the previous two years. This conference offered a conceptualization of hunger, focusing mainly on inadequate food supplies at the national and international levels. This "flat keying of the hunger frame" became consolidated under the influence of transnational corporations, the World Bank, the International Monetary Fund, the FAO, and the U.S. State Department, defining world hunger as a "global food supply" problem to be solved mainly by increased trade liberalization. In fact, the 1996 First World Food Summit precisely declared that "trade is the key element in achieving food security. We agree to pursue food trade and overall trade policies that will encourage our producers and consumers to utilize available resources in an economically sound and sustainable manner" (FAO 1996: 1).

Despite this statement, the liberalization of the agricultural economic sector - under regional free trade agreements and the World Trade Organization's (WTO) Agreement on Agriculture (AoA) signed in 1994 - has far from improved access to food and eradicated hunger. On the contrary, this economic neoliberal orientation has led, in particular in the "Global South", to a shift from agricultural production for domestic consumption to production for international external markets, throwing a country like India for instance into an unprecedented and severe agrarian distress (see Vasavi 2012). Among the numerous signs of the latter, the most dramatic one is the "epidemic of farmers' suicides" across the country ${ }^{8}$. Based on a strategy of exportled growth, the opening up of Indian agriculture to the world market led to the displacement of local food staples by the production of export crops in the name of the Ricardian theory of comparative advantages. The removal of trade barriers and quantitative restrictions to imports moreover placed millions of foodgrain producers under the threat of increased competition from foreign countries, which most often heavily subsidize their own farm products and thereby enable the export of vast quantities of low-priced grain (Patnaik 2003: 41). Consequently, many developing countries, which used to be self-sufficient in basic food commodities, are nowadays witnessing a new food dependency on the world economy, exposing small-scale farmers to the adverse fluctuations and volatility of international prices (Wise 2009: 867-868).

It is precisely to contest, as Philipp McMichael puts it, this "shift in the 'site' of food security from the nation-state to the world market engineered during the Uruguay Round" (2005: 281) that the concept of food sovereignty was introduced by La Via Campesina. It is noteworthy, however, that the above-mentioned declaration occurred on the sidelines of the 1996 First World Food Summit. Indeed, as part of a social movement, its delegates were not granted accreditation to attend the official Summit. Isabel Cruz Hernández, a Mexican delegate of $L a$ Via Campesina, precisely stresses the paradox of this exclusion:

We are the point of view closest to production and although our point of view isn't the only one, it is the missing element here [at the World Food Summit]. Communities of farmers and small producers see the globalization of food production from below. And from our point of view, this globalization of production is also producing a globalization of hunger (Bacon 1997).

The emergence of the food sovereignty concept "from below" exemplifies well the constraints within which a framing process takes place. It is indeed important to keep in mind that framing

\footnotetext{
${ }^{7}$ Drawing on Goffman's (1974) metaphor of "keying", Money and Hunt refer to a "flat keying" of a frame as a process "reinforce[ing] extant dominant interpretations and practices, usually advanced by power holders" (2009: 471).

${ }^{8}$ According to the National Crime Records Bureau (NCRB) of the Indian Ministry of Home Affairs, 150,000 farmers have committed suicide between 1997 and 2005.
} 
activity does not "occur in a structural or cultural vacuum" (Benford and Snow 2000: 628) ${ }^{9}$. In this perspective, it is interesting to note that La Vía Campesina's declaration refers dialogically to the "hegemonic discourse", that is to say to the predominant discursive repertoires shaping the international debate on the world hunger problem. It indeed invokes the "right to food", namely a human right recognized by the Universal Declaration of Human Rights, Article 25, and by the International Covenant on Economic, Social and Cultural Rights (1966), Article 11. Moreover, food sovereignty is defined as a right in itself. Over the past two decades, the language of rights - in particular the transnational discourse of human rights - has emerged as a common language of ethical obligations. As part of a "universalization project" (Kennedy 2002), the "language of rights" indeed provides the social agents with "a flexible vehicle for formulating interests and demands" as well as a means to "restate the interests of the group as characteristics of all people" (ibid.: 188). However, La Vía Campesina's activists did not comply passively with the human rights discourse. As a contentious process, the generation of interpretative frames inflicts new meanings in the hegemonic discourse, by seeking "to stretch, reshape, or even invert the meanings implied [in dominant languages]" (Li 2001: 653). Indeed, through the notion of food sovereignty, they invite their audience to take into consideration the conditions under which fundamental rights such as the "right to food" can be implemented so as to achieve "genuine food security." What is a "right to food" without the right of peoples to exercise sovereignty over their territory, which means also sovereignty over their land, water, seeds, and other natural resources? While adopting the language of rights, La Vía Campesina activists demonstrated skills in going beyond conventional human rights talk. By expanding and exploiting the "multivalent character of rights" (Polletta 2000: 392), they departed from a narrow individualistic, depoliticized, and state-dependent bias reflected in international standards. Advocating a "peoples' right" they insisted on self-determination and on the socioeconomic and political prerequisites essential to the realization and enjoyment of human rights.

\section{Bringing the Small Food Producers Back In}

The introduction of the food sovereignty frame allowed small farmers, traditionally marginalized in the public arena, to assert themselves as an independent voice in international debates on food and agricultural policies ${ }^{10}$. La Via Campesina's activists regularly express a demand for autonomy from political parties, churches, and NGOs. A delegate of the ICC for Europe, who was also a farmer in the South-West of France and a member of the Confédération Paysanne, asserted that La Vía Campesina was precisely born "to release small farmers from the yoke of NGOs' paternalism" and to "allow peasants organizations to speak autonomously" 11 . The founding meeting of the movement in 1993 precisely resulted in a radical clash with the Dutch NGO, Paulo Freire Stichting (PFS), which initially brought together farmer leaders in Mons (Belgium). The divergence in agendas between peasant leaders and the NGO staff person - that it to say between a militant stance and a more research and policy development perspective - has heavily marked to this day the ambivalent "love-hate"

\footnotetext{
${ }^{9}$ Myria Marx Ferree reminds us of the "relation of power to framing" (2003: 308); that is to say, the deep power asymmetries between social agents determining their ability to reshape an existing discursive field.

${ }^{10}$ The emergence of La Vía Campesina also signified a "break" with the influence of the International Federation of Agricultural Producers (IFAP) led mainly by commercially large-scale farmers and officially representing "farmers" interests at international and intergovernmental institutions since 1946. Since November 2010, IFAP has however been dissolved because of bankruptcy.

${ }^{11}$ Transcript of speeches held during a training workshop on "food sovereignty" organized by the Confédération paysanne (Bagnolet, France, 19 February 2009, my translation from French).
} 
relationship between La Vía Campesina and NGOs (Borras, Edelman, and Kay 2008: 28) ${ }^{12}$. For instance, as one of my interviewees who took part in the La Via Campesina's delegation in Rome explained, NGOs attending the 1996 World Food Summit failed to envision a social change and a political struggle beyond institutional and legal reform ${ }^{13}$; consequently, the delegates of the farmers' movement refused to sign the NGO Forum Statement and made a separate statement ${ }^{14}$ :

The right to food was on the NGO's agenda, not on ours. Because we thought that this legal dimension was too narrow. Law is only an instrument, it may be useful, but from our viewpoint, struggle primarily must be political. What we aim at is creating a people's initiative. The concept of "food sovereignty" was very much broader [than the "right to food"]. [...] So even if NGOs tried to pressure us during the parallel summit, we refused this concept because it sounded too restrictive. [...] Besides, for a long time, only NGOs were speaking on behalf of small farmers. The "right to food" was their concept, not ours. On the contrary, "food sovereignty" was a concept coined by us. So finally, we did not sign the final statement made up by NGOs. They got very angry because of that. (International staff of La Vía Campesina, July 2010, my emphasis, my translation from French)

The limitations of the "right to food" and "food security" approach also lie in the incapacity of these concepts to counter the increasing sway of agro-industries and transnational chemical corporations over the world's agricultural production and the global food system. On behalf of the "right to food", Cargill for instance has pointed out the possibility to finance food programs, but with the intention of leaving "the power structures [of the system of production] intact and more profitable than ever" (Kneen 1999: 165). Through the concept of "food sovereignty", La Via Campesina thus aims to bring back to the forefront of the public debate on world hunger the social basis of food production and the need to address some fundamental issues within the existing global food system: Where does food come from? How is it grown? And above all, by whom is it produced? As Jan Douwe Van Der Ploeg underlines, a prominent feature of the globalization of agriculture is precisely to "create invisibility [...] since production is moved to 'non-places' where the origin of food (or its many ingredients) is hidden behind the façade of lookalike products, and primary producers are made anonymous and interchangeable. They tend to be converted into "non-persons' whose identities and skills do not matter" (2008: 269). The construct of "food sovereignty" was coined by the activists of the international movement La Via Campesina to challenge the widespread blindness of how food is produced and to expose the silence ${ }^{15}$ towards the "social control of the food system" (Patel 2009: 665).

What is at stake in the globalization process is thus the recognition that small farmers and peasant agriculture are the "key part of the solution" (La Vía Campesina 2008) to eradicate world hunger and to democratize the agri-food system. From this perspective, the current international coordinator of La Vía Campesina, Henry Saragih, called for a shift in the commonly-held "right to food" perspective, claiming that "the right to produce food is much

\footnotetext{
12 As Saturnino Borras Jr, Marc Edelman, and Cristóbal Kay underline, "For Vía Campesina, it is not the NGOs per se that are problematic. Rather it is the term of the relationship that matter" (2008: 29), that is to say the relations of power stemming from great disparities in resources and goals. In this sense, the movement seeks to build alliances with a few progressive NGOs sharing a similar vision and concerned with the establishment of an equal partnership (Food First Information and Action Network, Land and Research Action Network, ATTAC, Oxfam, GRAIN, etc.).

13 This strategy to "keep resonance" (Ferree 2003) with international conventional food security discourse through the adoption of a "reformist" stance may be related to NGOs' dependence on governmental and international donors to get funds.

14 "Statement by the NGO Forum to the World Food Summit" (17 November 1996, Rome).

${ }^{15}$ Marc Steinberg precisely points out that "an essential part of the power produced through discourse, and a cornerstone of hegemony, is the capacity to construct silences within common sense" (1998: 855).
} 
more fundamental to fulfilling the rights to food" (2005: 7, my emphasis). For the "right to produce" of small farmers is more and more in jeopardy when faced with the growth of corporate power in agriculture. Paradoxically, while rural peasants make up almost half of the world population and grow at least 70 percent of the world's food, "hunger is mainly among the rural peasants, small landholders, landless workers, fisher folk, hunters and gatherers suffer disproportionately. [...] Some 50 percent of the world's hungry are small holder farmers who depend mainly or partly on agriculture for their livelihoods, but lack sufficient access to productive resources" (Saragih 2010).

Refusing that small holders are doomed to extinction, La Vía Campesina's activists reclaim the small farmers' status as food producers, laying emphasis more particularly on their "food producing vocation" for the nation (2010: 5). Contradicting Cargill and Monsanto's claim that transnational corporations "feed the world" (Kneen 1999: 162), they underline for instance - relying on data from Brazil - that most of the food consumed within the country is due largely to peasants and family farmers:

In country after country, small farmers control less than half of the farm land, yet produce the majority of the food that is consumed [...]. A typical example comes from the most recent agricultural census in Brazil [...]. Peasants have less than $25 \%$ of farm land, yet they generate $40 \%$ of all agricultural value [...]. It is still Brazilian peasants and family farmers that feed the Brazilian people, a pattern repeated around the world. [...] Brazilian agribusiness is more likely to feed cattle in Europe or produce ethanol for automobiles than it to feed a hungry child in Brazil. (La Vía Campesina 2010: 4-5)

In my fieldwork in Brazil with organizational members of La Via Campesina-Brazil ${ }^{16}$, interviewees always attached importance to showing me the productive capacity of their farm or the assentamento ${ }^{17}$ where they were living. They would show me round the farm or the plot of land, walk me through the fields, display seeds from different crop varieties, explain the making of biodynamic liquid manure, or take me to visit the new small agro-industrial factory. These actions affirmed the centrality of their identity as producers.

La Vía Campesina's self-assertion as a movement of food producers, resisting and confronting the global corporate food system, also comprises a dramaturgical and public dimension in Goffman's sense. Constituting themselves as "dramatis personae", as "a We opposed to a They in a cast of characters" (Cefaï 1998: 146), activists from the movement assert their right to grow food and to feed themselves by making themselves visible at public meetings and global civil society gatherings. At the People's Climate Summit parallel to the United Nations Climate Change Conference (COP 15) held in Copenhagen (Denmark) in December 2009, about forty delegates of La Vía Campesina from Europe, Asia, Africa and Americas performed what the movement calls mística (or "mystique"). They denounced the international food regime based on cheap GM soya exports from Brazil for the large scale and intensive European meat industry. Standing in a circle in front of the Danish Agriculture \& Food Council, some, with La Via Campesina green scarves around their necks, held baskets full of vegetables, flowers, and armfuls of wheat ears as symbols of abundance and plenty. Others, dressed up like pigs and representing the agro-meat industry, were covered with posters displaying the names of the transnational corporations. Miming a fight between the two camps, the activists embodied the dialectic between their struggle and their hope ${ }^{18}$, their present condition and the future as they envision it, namely, the final victory of small farmers over the global corporate power. The

\footnotetext{
${ }^{16}$ Movimento dos Trabalhadores Rurais Sem Terra, Movimento das Mulheres Camponesas, Movimento dos Pequenos Agricultores, Movimento dos Atingidos por Barragens.

${ }^{17}$ Assentamento refers to a permanent settlement established once the landless families win the land they occupied. It is divided in family or common lots.

${ }^{18}$ La Via Campesina's slogan is "Globalize the Struggle - Globalize the Hope!"
} 
mística - a cultural and political practice that La Via Campesina borrowed from the Movimento dos Trabalhadores Rurais sem Terra (Landless Rural Workers Movement/MST) and which derives from liberation theology - plays a significant role in the movement. Present in many opening and closing meetings, it usually consists of a playlet, songs, poetry, or dance, intended to represent symbols ${ }^{19}$ of the social change activists yearn to create ${ }^{20}$. By enhancing among them the feeling of being part of a common struggle, but also by allowing them to recharge collectively their "emotional batteries", it thus operates as a powerful consolidating element of the movement and sustains further commitment from its participants.

La Vía Campesina regularly engages in other symbolic rituals expressing their resistance to the corporate agri-food system. Of particular importance is the exchange or distribution of seeds originating from their respective countries. Annette Aurélie Desmarais for instance explains that at the 1996 World Food Summit, the movement "distributed its declaration accompanied with a package of seeds to all delegates attending the official summit [...]. It also brought truckloads of earth into the city [Rome] to form a plot of land and representatives engaged in a symbolic act of planting seeds" (2008: 141). La Via Campesina's critical stance toward the corporate domination of the current agrifood system is also made visible through direct actions. Framed as the main "enemy" of the movement, transnational agrifood, agrichemical, and seed corporations (such as Monsanto, Syngenta, Du Pont, Bayer, Cargill, BASF, Dow, Limagrain, etc.) are indeed the major target of activists' disruptive strategies. Apart from more or less routine repertoires of action, such as marches and demonstrations, activists engage in actions outside legality, which are likely to seize the attention of the media. Two examples of such illegal actions may be highlighted. On 26 January 2001, at the sidelines of the first World Social Forum held in Porto-Alegre (Rio Grande do Sul), about 1,200 activists from the MST, Vía Campesina-Brasil, and La Vía Campesina-International ${ }^{21}$ occupied a Monsanto biotech experimental farm and research center in the heart of the soy growing region (Não-me-Toque). Newspapers reports indicate that "the protestors uprooted soy and corn crops, burned soy stored in warehouses and held a burial ceremony for a coffin marked 'Monsanto' and covered with a U.S. flag"22. Three years earlier in India, on the symbolic date 9 August $1998^{23}$, the Karnataka Rajya Ryota Sangha (Karnataka State Farmers' Association/KRRS) and a coalition of Indian NGOs launched a campaign, "Quit India Monsanto". They opposed the "re-colonization of India" by transnational corporations through the WTO agreements. KRRS activists undertook several occupations of Monsanto's field trials and burned Bt cotton crops grown there ("Operation Cremate Monsanto") (Kingsnorth 1999).

\section{Food Sovereignty and Social Transformation}

La Vía Campesina's food sovereignty framing catalyzed small farmers' mobilization across borders and allowed them to become a voice of resistance increasingly heard in international

\footnotetext{
${ }^{19}$ Daniela Issa emphasizes the importance of the use of symbols in the practice of mistica because of the peasant culture's oral tradition (2007: 133).

${ }^{20}$ According to Ademar Bogo, a former Catholic seminarian, the objective of the mística is "to reduce the distance between the present and the future, helping us to anticipate with certainty the objectives we want to reach" (Jornal dos Sem Terra, May 1991, n¹03: 3, my translation from Portuguese).

${ }^{21}$ The French José Bové and François Dufour from the Confédération paysanne and the Honduran Rafael Alegría, Second International Coordinator of La Via Campesina, also took part into the action.

${ }^{22}$ Agencia Latinoamericana de Información, La Jornada, Financial Times, 27 January 2001. See also Jornal dos Sem Terra, February 2001, n²07: 11.

${ }^{23}$ In the midnight of 8-9 August 1942, the "Quit India" movement, a civil disobedience movement, was launched in response to Gandhi's call for immediate independence.
} 
and domestic policies. However, the movement is concerned with not limiting itself to transnational advocacy work. Far from focusing only on small-scale farmers' and rural workers' rights against transnational corporations and the WTO, the movement has much broader aspirations: "Our objective is always social change. We really define ourselves as a movement that wants to transform society..." ${ }^{24}$. According to most activists I met, struggling for food sovereignty principles requires consistency both in their farming practices and in the shaping of their social relationships. This process goes through a reversal of values and priorities of the dominant corporate food system (Schanbacher 2010: 99). Stating that "food is first and foremost a source of nutrition and only secondary an item of trade" (La Via Campesina 1996), the movement aims at reorienting agriculture from an exclusive focus on commodification, so as to give priority to its broader cultural, social, and environmental function.

The new global agriculture regime resting on industrialization and the promotion of exogenous methods, such as agri-chemical inputs and genetically modified (GM) seeds, amounts to a process of "abstraction" (McMichael 2005: 286), namely, the disembedding of the social, but also ecological and cultural basis of agriculture. Agriculture is increasingly "systematized", homogenized, and de-contextualized, disregarding the plurality and diversity of local contexts (for instance, local variations of the soil and climatic conditions). As A.R. Vasavi underlines, "It largely displaces the local knowledge and autonomy of agriculturists and substitutes the uniform and market-oriented prescriptions of the bureaucracy" (1994: 294). While agriculture is becoming increasingly globalized and centralized, "eliminating [...] selfreliance, self-provisioning, and autonomy" (Kneen 1999: 163), the sense of the political struggle lies also "at the farm level" as a member of the South Indian Coordination Committee of Farmers Movements (SICCFAM) ${ }^{25}$ highlights it:

It is not only a political fight against corporates [...] it is also on the ground, at farm level. For example, I am telling you, I'm working for the farmers' movement, but my father is not really listening to me... for example, I asked him 'Who has given you these seeds?' - 'I do not know the company!' Then I discovered it is from Syngenta. So multinational corporations are there even in my field! So, it has to be the change from the farm-level resistance. Every farm should become selfreliant. This is another way we can have the chemical and seeds companies out. [...] So, the fight... the struggle should be from farm-level to political level. Both levels the fight should go on, hand in hand. Otherwise, farmers who are taking place in the struggle against multinational companies would continue to use multinational seeds, chemicals, everything... in their farms. So, it should be a people's movement in the countries where the people should be able to keep the companies out of their farms. (Indian, male, Bangalore, November 2011)

From this perspective, La Vía Campesina engages in modeling alternative agri-food systems by promoting "seed sovereignty" (that is to say, farmers' rights to save, use, exchange, sell, and protect farm-saved seeds) ${ }^{26}$ and agro-ecological practices at the global, regional, national, and local level. Native seed conservation projects have been established in several peasant farm communities in Brazil, among them Bionature Agroecological Seeds, founded in 1997 in the south of Rio Grande do Sul. Activists from the MST furthermore receive training courses in sustainable agriculture at the Chico Mendes Center for Agroecology (Ponta Grossa, Paraná) as well as in the Latin American School of Agroecology (Varinas, Venezuela since 2005 - thanks to a partnership between the Federal government of Venezuela, the Federal University of Paraná, and La Vía Campesina. Small Brazilian delegations are also involved in "international brigades" so as to promote and disseminate a self-reliant and input-free orientated agriculture

\footnotetext{
${ }^{24}$ Paul Nicholson, personal interview, Irun, Spain, April 2010, my translation from French.

${ }^{25}$ The SICCFM is a coalition of South-Indian farmers' unions taking part in La Via Campesina and founded in 2009.

${ }^{26}$ From 2003 onwards, La Via Campesina launched a global campaign "Seeds: Heritage of Rural Peoples in the Service of Humanity", coordinated by women activists.
} 
among peasants in other countries, such as in Haïti since 2009 ("Dessaline Brigade"). Likewise, the KRRS promotes agro-ecology by organizing training and exchange programs about the methods of "Zero Budget Natural Farming" (ZBNF): for instance, from 1-6 November 2011, an international delegation of about forty representatives of Asian farmers organizations of $L a$ Via Campesina shared their experiences and visited farmers practicing "natural farming" in the surroundings of Mysore (Karnataka, India). Peter Rosset, a Mexican American who provides technical support for the Sustainable Peasant Agriculture Commission of La Vía Campesina, outlined the social transformation issue at stake at the closing conference of the Mysore workshop:

As a social movement promoting agro-ecology, we are not just talking about farming techniques, we are really talking about something much larger: we are talking of agro-ecology as part of a much larger transformation of society, as one piece of an overall struggle for another kind of society. [...] We see agro-ecology as a tool for the transformation of our rural reality, by collective action, by working together and sharing knowledge, and we see agro-ecology is very exciting to many farmers, it is socially activating, it gets people working together and cooperating with each other and this is the first step for transforming a larger reality. (Public meeting at B.N. Bahadur Institute of Management, Mysore University, 6 November 2011, my transcription)

In addition to transforming the farming system, the movement aims to eliminate the social inequalities of power relationships within the existing international food system, notably through a global campaign for agrarian reform and claims to fair prices for farmers. But La Vía Campesina also addresses the need for a deeper social change and understanding of power and control in society. The movement indeed points out the "equality-distorting effects of sexism, patriarchy, racism, and class power" (Patel 2009: 670). This association of food sovereignty with emancipatory politics includes in particular a feminist perspective that emphasizes the critical roles and rights of women and indigenous peoples in food production. So as to ensure women's increased participation and representation in food and agriculture policy, the movement committed - only one year after its foundation - to fighting against patriarchalism and achieving gender equality within it. The $\mathrm{ICC}^{27}$ emphasized gender parity, and an International Commission of Gender was established to promote feminist and leadership training courses for peasant women ${ }^{28}$. In addition, since 2000, an International Women's Assembly precedes International Conferences of the movement. Annette Aurélie Desmarais outlines the specific contribution that women taking part in La Via Campesina played in defining food sovereignty in 1996 (2007b: 143), notably by adding a human health dimension to the "right to food." "Food is a basic human right. Everyone must have access to safe, nutritious and culturally appropriate food in sufficient quantity and quality to sustain a healthy life with full human dignity" (La Vía Campesina 1996, my emphasis). This is precisely the health dimension that the woman in charge of the MST national sector of food production stresses, describing a direct action undertaken on International Women's Day (8 March, 2007) in Fortaleza (Ceará):

Until recently, the sector of food production in the MST was very male-dominated. But the companheiras [women comrades] organized themselves. For instance, they organized a mobilization against a McDonald's. They put in huge outside street kitchens, along five meters of the sidewalk, just in front of the fast-food restaurant. Then they cooked traditional meals such as feijadas, based upon recipes they inherited from their grandmothers who were European migrants or African slaves... You know, they cooked meals that are very nutritious, that really give energy and health and also that highlight the great cultural diversity of Brazil. So we shouted out in the street to passersby: "Which would you prefer? Diversity, health, quality of life or limitation in the breadth and

\footnotetext{
${ }^{27}$ The ICC includes one woman and one man from each of La Via Campesina's regions.

${ }^{28}$ A World Congress of Women of La Vía Campesina was for instance organized at Santiago de Compostela, Spain, from 18 to 21 October 2006.
} 
choices of food?" Companheiras are not against the "right to food", this is very good, but we must specify: the right to healthy food, not just food for food! Not only arroz e feijão [rice and beans stew], neither chemicalized and pesticized food! (Brazilian woman, headquaters of the MST, São Paulo, my translation from Portuguese)

Finally, the movement engages in exploring the inequalities in power that characterizes the agri-food system, from the domestic to the global level. While women often bear the brunt of the rural work, they have less secure access to land and to productive resources than men. Chukki Nanjundaswamy, a female delegate of La Via Campesina for Asia from 2004 to 2008 and general secretary of the KRRS, indeed notes that "Socially, Indian peasant women have almost no rights and are considered an addition to men. Peasant women are the most untouchable of the untouchables within the social caste system" (La Vía Campesina 2006: 16, my translation). They also undergo underpaid agricultural employment. At the fifth International Conference in Maputo (Mozambique) in October 2008, La Vía Campesina officially endorsed the idea that to democratize the food system requires challenging this situation. The assembly therefore approved the launch of a campaign targeting all forms of violence (physical, sexual, social, cultural, economic, etc.) faced by women in rural areas as well as in the broader society, stating, "Food sovereignty is about an end to violence against women".

This chapter has explored how rural social agents from the South and from the North, marginalized by the current trends of economic globalization, have engaged since the 1990s with a specific mode of agrifood activism organized across borders. Facing worldwide destruction of local agricultural production through corporate monopolization of agriculture and the increasing concentration in the food chain, small-holder farmers and landless rural workers taking part in La Via Campesina point out the contradictions of the current food system, as it engenders hunger amidst abundance. Desiring to bring back to the forefront of the public arena the social basis of production, they resist the disempowering aspects of economic globalization by making themselves more visible as food producers in the international arena. They confronted the hegemonic concept of "food security" by elaborating an alternate frame, "food sovereignty", that is to say the right of peoples to define their agricultural and food policies. By actively appropriating language of rights and coining a more political concept, activists of La Via Campesina offer a powerful tool for reorienting the global politics of food away from an exclusive focus on commodification and rethinking it in terms of selfdetermination, social justice, public health, cultural appropriateness, and sustainability. This chapter also provides insights into the way La Via Campesina's agrifood activism has aimed, over the last twenty years, at fostering a broader social change through the promotion of selfreliant agro-ecological farming practices and the shaping of new social relationships based on gender equality. While small farmers and landless rural workers taking part in La Via Campesina have undoubtedly succeeded in redefining their areas of action and resistance by transcending local and regional boundaries, strengthening the links with urban struggles for "food justice" remains one of the challenges facing them in the coming years. 


\section{REFERENCES}

Bacon, D. (1997), 'Still Hungry', Z Net: The Spirit of Resistance Lives. Available from: http://www.zcommunications.org/still-hungry-by-david-bacon.

Benford, R. and Snow, D. (2000), 'Framing Processes and Social Movements: An Overview and Assessment', Annual Review of Sociology, 26: 611-639.

Benford, R. and Hunt, S.A. (2003), 'Interactional Dynamics in Public Problems Marketplaces: Movements and the Counterframing and Reframing of Public Problems', in J.A. Holstein and G. Miller (eds), Challenges and Choices: Constructionist Perspectives on Social Problems, New York: De Gruyter.

Borras Jr, S.M. (2008), 'La Vía Campesina and its Global Campaign for Agrarian Reform', Journal of Agrarian Change, 8(2-3): 258-289.

Borras Jr, S., Edelman, M., and Kay C. (2008), 'Transnational Agrarian Movements: Origins and Politics, Campaigns and Impact', in S.M. Borras Jr, M. Edelman and C. Kay (eds), Transnational Agrarian Movements. Confronting Globalization, Malden, Mass: WileyBlackwell Publishing.

Cefaï, D. (1998), 'Making Sense of Politics in Public Spaces: Phenomenology of Political Experiences and Activities', in L. Embree (ed), Schutzian Social Science, The Hague: Kluwer Editions.

Desmarais, A. (2007a), La Vía Campesina: Globalization and the Power of Peasants, Halifax and London: Fernwood Publishing and Pluto Press.

Desmarais, A. (2007b), 'The Vía Campesina. Peasant Women on the Frontiers of Food Sovereignty', Canadian Woman Studies/Cahiers de la femme, 23 (1): 140-145.

Desmarais, A. (2008), 'The Power of Peasants: Reflections on the Meanings of La Vía Campesina', Journal of Rural Studies, 24: 138-149.

FAO (1996), "Rome Declaration on World Food Security".

Ferree, M.M. (2003), 'Resonance and Radicalism: Feminist Framing in the Abortion Debates of the US and Germany', American Journal of Sociology, 209 (2): 304-344.

Goffman, E. (1974), Frame Analysis: An Essay on the Organization of Experience, New York: Harper \& Row.

Hrabanski, M. (2011), 'Souveraineté alimentaire. Mobilisations collectives agricoles et instrumentalisations multiples d'un concept transnational', Revue Tiers Monde, 3 (207): 151-168.

Issa, D. (2007), 'Praxis of Empowerment: Mística and Mobilization in Brazil's Landless Rural Workers' Movement', Latin American Perspectives, 34 (2): 124-138.

Kennedy, D. (2002), 'The Critique of Rights in Critical Legal Studies', in W. Brown and J. Halley (eds), Left Legalism/Left Critique, N.C.: Duke University Press.

Kingsnorth, P. (1999), 'India Cheers While Monsanto Burns', The Ecologist, 28 (1): 9-10.

Kneen, B. (1999), 'Restructuring Food for Corporate Profit: The Corporate Genetics of Cargill and Monsanto', Agriculture and Human Values, 16: 161-167.

La Vía Campesin.a (1996), 'The Right to Produce and Access to Land. Position of the Vía Campesina on Food Sovereignty Presented at the World Food Summit'. 
La Vía Campesina. (2006), 'Labregas sementando igualdade', Congreso Mundial de Las Mujeres de La Vía Campesina: Santiago de Compostela, Spain.

La Vía Campesina. (2008), 'Vía Campesina Proposal to Solve Food Crisis: Strengthening Peasant and Farmer-based Food Production', open letter to Mr Jacques Diouf Secretary General of the Food and Agriculture Organization of the United Nations, Jakarta, April 28".

La Vía Campesina. (2010), 'Sustainable Peasant and Family Farm Agriculture Can Feed the World': Jakarta.

Li, T. Murray. (2001), 'Masyarakat Adat, Difference and the Limits of Recognition in Indonesia's Forest Zone', Modern Asia Studies, 35 (3): 654-676.

Martínez-Torres, M.E. and Rosset, P.M. (2010), 'La Vía Campesina: The Birth and Evolution of a Transnational Social Movement', Journal of Peasant Studies, 37 (1): 149-175.

McMichael, P. (2005), 'Global Development and the Corporate Food Regime', in F. Buttel and P. McMichael (eds), Research in Rural Sociology and Development (New Directions in the Sociology of Global Development, Volume 11), Amsterdam: Elsevier.

Money, P.H. and Hunt S.A. (2009), 'Food Security: The Elaboration of Contested Claims to a Consensus Frame', Rural Sociology, 74 (4): 469-497.

Patel, R. (2009), 'What Does Food Sovereignty Look Like?', The Journal of Peasant Studies, 36 (3): 663-673.

Patnaik, U. (2003), 'Global Capitalism, Deflation and Agrarian Crisis in Developing Countries', Journal of Agrarian Change, 13 (1-2): 33-66.

Polletta, F. (2000). 'The Structural Context of Novel Rights Claims: Southern Civil Rights Organizing, 1961-1966', Law \& Society Review, 34 (2): 367-406.

Saragih, H. (2005), 'The World Peasant Farmers Need a Peasant Farmers Rights Convention: The Way for the United Nations to End the Oppression and the Extinction of Peasant Farmers'. Available from: http://www.cetim.ch/en/doocuments/05-onu2-saragih.pdf

Saragih, H. (2010), 'Rights of Peasants: Ending the Discrimination Against Peasants', speech delivered on 27 January 2010, at the Fourth Session of the Advisory Committee of UN Human Rights Council, Geneva, responding to the report of the Advisory Committee 'Discrimination in the context of Right to Food' (A/HRC/AC/4/2).

Schanbacher, W. (2010). The Politics of Food. The Global Conflict between Food Security and Food Sovereignty, Santa Barbara/Denver/Oxford: Praeger.

Snow, D., Benford, R., Rochford, E.B. Jr., and Worden S.K. (1986), 'Frame Alignment Processes, Micromobilization, and Movement Participation', American Sociological Review, 51: 464-481.

Steinberg, M. (1998). 'Tilting the Frame: Considerations on Collective Action Framing from a Discursive Turn', Theory and Society, 27 (6): 845-872.

Steinberg, M. (1999), 'The Talk and Back of Collective Action: A Dialogic Analysis of Repertoires of Discourse among Nineteenth Century English Cotton Spinners', American Journal of Sociology, 105 (3): 736-780.

United Nations General Assembly (1948), Universal Declaration of Human Rights, Paris.

United Nations General Assembly (1966), International Covenant on Economic, Social and Cultural Rights (1966), New York. 
Vasavi, A.R. (1994), 'Hybrid Times, Hybrid People: Culture and Agriculture in South India', Man, New Series, 29 (2): 283-300.

Vasavi, A.R. (2012), Shadow Space. Suicides and the Predicament of Rural India, Gurgaon: Three Essays Collective.

Van Der Ploeg, J.D. (2008), The New Peasantries. Struggles for Autonomy and Sustainability in an Era of Empire and Globalization, London/ Sterling, VA: Earthscan.

Wise, T.A. (2009), 'Promise or Pitfall? The Limited Gains from Agricultural Trade Liberalisation for Developing Countries', Journal of Peasant Studies, 36 (4): 855-870. 